\title{
AN EVALUATION OF COMMERCIAL TEXTILE TANNINS BASED ON THEIR INERT COD CONTENT AND TOXICITY
}

\author{
TEZGEL T. \\ GERMIRLI BABUNA F. \\ ISKENDER G.
}

\author{
Istanbul Technical University \\ Civil Engineering Faculty \\ Environmental Engineering Department \\ 34469, Maslak, Istanbul, Turkey
}

Received: 17/09/2013

Accepted: 26/09/2013
* to whom all correspondence should be addressed: e-mail: germirliba@itu.edu.tr

\begin{abstract}
This study investigates inert COD levels and toxicity of two different commonly applied textile dye auxiliaries, namely two tannin formulations (Tannin 1: a condensation product of aryl sulphonate; Tannin 2: a sulfonated phenol polymer). The experimental evaluation is performed on samples obtained by simulating the textile bath discharges carrying the tannin formulations. The acute toxicity of tannins is assessed by employing the photobacterium Vibrio fischeri. The results obtained indicated that both of the tannin formulations have high levels of initially inert soluble COD, $\mathrm{S}_{\text {, }}$ accounting for 59 and $41 \%$ of the total COD, respectively. Such an outcome necessitates a specific pretreatment on segregated effluents containing these formulations. Acute toxicity data showed that both of the formulations are toxic towards Vibrio fischeri, although Tannin 2 exerts considerably higher toxicity.
\end{abstract}

KEYWORDS: Microtox, inert COD, recalcitrance, auxiliaries, textile, toxicity

\section{INTRODUCTION}

Substitution of recalcitrant and toxic auxiliary chemicals with eco ones is considered to be among the most important in-plant control measures applied to industrial premises aiming waste minimization at source. In some cases however it is not possible to substitute xenobiotic auxiliaries with low biodegradability and high toxicity by ecochemicals due to potential constraints such as the inadequacy of the investments allocated, inaccessibility of the ecochemicals etc. Under such conditions an alternative waste management strategy has to be developed. During industrial production a part of the various auxiliary chemicals added may end up as constituents of various waste streams. The waste streams having high recalcitrance and toxicity can be directed towards a pretreatment prior to be mixed and treated with biodegradable ones. This pretreatment must be a specific one tailored to reduce recalcitrance and toxicity. In this context the inert and toxic nature of segregated industrial effluent streams susceptible of carrying recalcitrants auxiliaries must be confirmed by the help of experimental assessment. Recently intensive research effort is dedicated to evaluate the biodegradability and toxicity of industrial auxiliaries (Germirli Babuna et al., 2007; Arslan Alaton et al., 2006a; 2006b; 2007). Tannin formulations are among the frequently applied textile dyeing auxiliaries. Tannins are added during the dyeing process after the rinsing stage to increase the dye fixation rates and to improve wet fastness onto the dyed fabric. There exist many different commercially available tannin formulations. Some of them can be categorized as extremely toxic, while others as highly recalcitrant chemicals (Burkinshaw and Bahojb-Allafan, 2003). According to the current understanding of environmental biotechnology that adopts multi-component approaches, the inert organic contents of effluents gain importance. The growth rate coefficients based on readily biodegradable organics on the other hand can be regarded as relatively insignificant tools. 
The objective of this study is to comparatively evaluate commonly applied textile tannins in terms of their inert COD content and toxicity towards marine bacteria Vibrio fischeri. All the assessments are performed on simulated textile bath effluents where the tannin formulations are added.

\section{MATERIALS AND METHODS}

Tannins under investigation

Physicochemical and ecotoxicological characteristics of tannin formulations as obtained from material safety datasheets (MSDS) are tabulated in Table 1.

Table 1. Characteristics of tannin formulations

\begin{tabular}{|c|c|c|}
\hline Property & Tannin 1 & Tannin 2 \\
\hline Appearance & Brownish liquid with smell of ammonia & Yellowish-brownish clear viscous liquid \\
\hline Ingredients & $\begin{array}{l}\text { A methylene linked condensation product } \\
\text { of arylsulphonic acids and } \\
\text { hydroxyarylsulphone }\end{array}$ & $\begin{array}{l}\text { Sulfonated phenol polymer with } \\
\text { formaldehyde, } 1 \text {-methoxy-2-propanol } \\
\text { and phenol }\end{array}$ \\
\hline Density $\left(\mathrm{g} \mathrm{cm}^{-3}\right)$ & 1.2 at $23^{\circ} \mathrm{C}$ & 1.17 \\
\hline $\mathrm{pH}$ & $8-9$ at $23^{\circ} \mathrm{C}$ (in $100 \mathrm{~g} \mathrm{l}^{-1}$ water) & $2.5-3.5$ (in $100 \mathrm{~g} \mathrm{l}^{-1}$ water) \\
\hline Solubility & Miscible & Soluble in cold water \\
\hline Viscosity (mPa s) & $<100$ at $23{ }^{\circ} \mathrm{C}$ & 2500 \\
\hline $\begin{array}{l}\text { Acute oral toxicity } \\
\left(\mathrm{LD}_{50^{*}}, \mathrm{mg} \mathrm{kg}^{-1}\right)\end{array}$ & $>5000$ & $>2000$ \\
\hline $\begin{array}{l}\text { Fish toxicity } \\
\left(\mathrm{LC}_{50^{\star \star}}, \mathrm{mg} \mathrm{I}^{-1}\right)\end{array}$ & $>1-10$ (Test duration, $48 \mathrm{~h}$ ) & $1-10$ (Test duration, 96 h) \\
\hline $\begin{array}{c}\text { Toxicity } \\
\left(\mathrm{LC}_{50^{\star \star \star}}, \mathrm{mg} \mathrm{I}^{-1}\right)\end{array}$ & ND & $1-10$ (Test duration, $48 \mathrm{~h}$ ) \\
\hline
\end{tabular}

The same chemical or wastewater can exert different levels of toxicity towards different organisms. Although both of the tannin formulations have low acute oral toxicities, when evaluated in combination with the typical concentrations encountered in spent textile baths, the values tabulated for acute fish toxicity can be considered as potentials of toxicity for the formulations. Table 1 presents aquatic toxicities of the tannin formulations on two organisms; namely Leuciscus idus as a fish specie and water flea Daphnia magna as a crustacean specie. By performing toxicity tests on Vibrio fischeri bacteria, this study adds new data to literature. Fish, bacteria and crustaceans represent different tropic levels. A sound evaluation of substitutable chemicals can only be realized when complementary toxicity data on fish, bacteria and crustaceans are uploaded to an ecosystem model (Heinlaan et al., 2008).

\section{Samples used}

As given in Figure 1 the tannin formulations are added to the textile baths during dye fixation stage where pre-treated textile material is processed at $70{ }^{\circ} \mathrm{C}$ at a pH of 4 for about 20 minutes. Both of the tannin formulations are applied at a concentration of $4 \mathrm{~g} \mathrm{I}^{-1}$ to the textile baths (i.e. $4 \%$ of fabric weight) and, approximately, $25 \%$ of the formulations remain unfixed in the exhausted textile bath. Therefore spent textile baths (where tannin formulations are added) are simulated by dissolving 1 gram of formulations (both Tannin 1 and Tannin 2) in 1 litre water. $\mathrm{pH}$ adjustment is performed with acetic acid addition for both of the tannin containing samples.

\section{Assessment of inert COD}

The inert COD content of samples, were assessed according to an experimental procedure given in literature (Germirli et al., 1993). The method involves running two aerated cylindrical batch reactors, one fed with the sample itself, and the other with glucose solution having the same dilution, of 3000 $\mathrm{ml}$ volumetric capacity. The seed was obtained from a lab-scale fill and draw aerobic reactor operated under steady state with a food to microorganism ratio (F/M) of $0.7 \mathrm{mg} \mathrm{COD} \mathrm{(mg} \mathrm{VSS} \mathrm{day}{ }^{-1}$ ) for about 40 days. $100 \mathrm{ml}$ of sludge was wasted from the reactor daily. A mixture of $50 \%$ glucose and $50 \%$ sample was applied as the feed for this fill and draw aerobic reactor used to obtain the 
seed. Then initial biomass concentrations of $50 \mathrm{mg} \mathrm{l}^{-1} \mathrm{VSS}$ were sustained in two batch reactors (run with sample and with glucose) where inert COD tests were performed to hinder the interference of the residual COD that can form from the endogenous respiration of initial inoculums. By adopting such a low sludge concentration in these reactors the adsorption of biomass as a mechanism for the removal of organic matter was neglected. Aliquots removed periodically from the mixed liquor of each reactor were analyzed for soluble COD. Experiments were continued and data were collected until the observation of a stable soluble COD plateau where the threshold level was established as less than 3-5\% variation between consecutive samples. In the batch tests the samples were adjusted to a $\mathrm{pH}$ of 7-8, a range suitable for biological activity. Nitrification inhibitor (Formula 2533TM, Hach Company) was added to all bioreactors in order to avoid possible interferences.

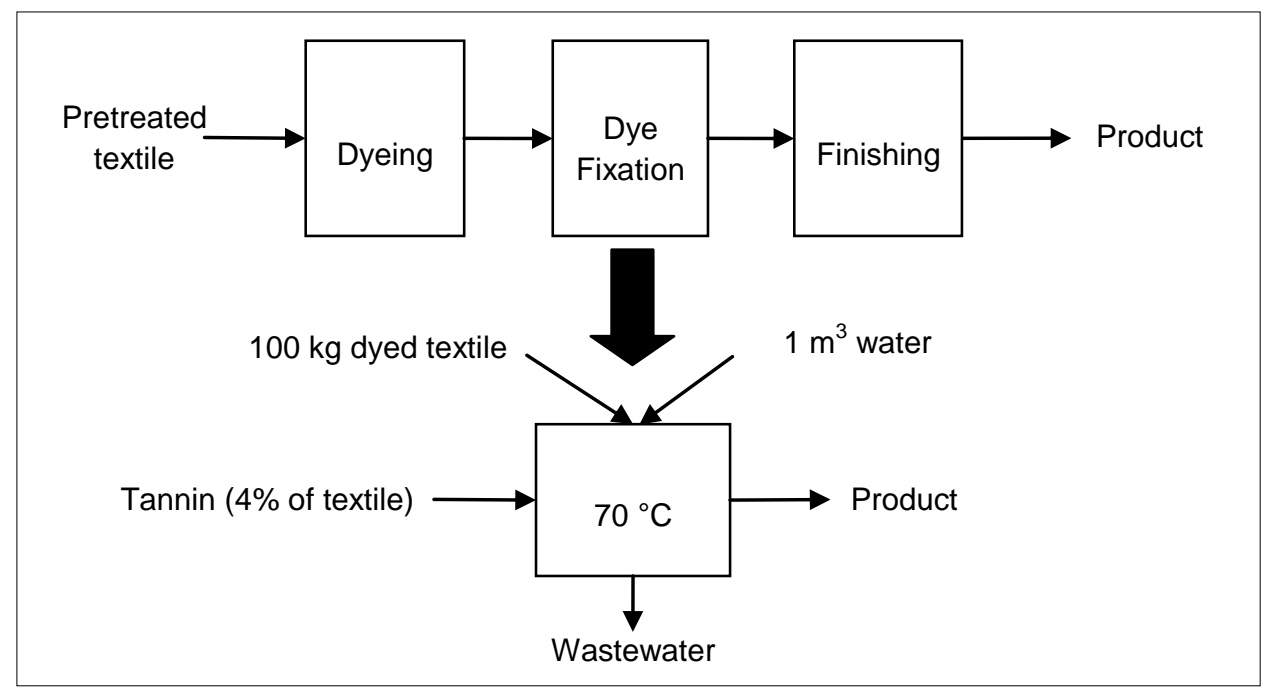

Figure 1. Process flowchart

\section{Assessment of toxicity}

In this study, toxicity experiments are carried out with bioluminescence marine bacteria Vibrio fischeri by BO1243-500 BioTox ${ }^{\mathrm{TM}}$ Kit. The inhibitory effect of the sample on the light emission of luminescent bacteria is measured with luminometer. The inhibition percentage (\% INH) is calculated according to the formula given below.

$\% \mathrm{INH}=100-\left[\left(\frac{\mathrm{IT}}{\mathrm{KF} \times \mathrm{T}_{0}}\right)\right] \times 100$

where;

$\mathrm{KF}=$ Correction factor, $\left(\frac{\mathrm{IC}_{\mathrm{t}}}{\mathrm{IC}_{0}}\right)$

$I_{\mathrm{t}}=$ Luminescence intensity of control after contact time, $\mathrm{t}$

$\mathrm{IC}_{0} \quad=$ Initial luminescence intensity of control

$\mathrm{IT}_{\mathrm{t}}=$ Luminescence intensity of test sample after contact time, $\mathrm{t}$

$\mathrm{IT}_{0} \quad=$ Initial luminescence intensity of test sample

The inhibition percentages $(\% \mathrm{INH})$ versus dilution factor plots are used to calculate effective concentrations causing different percentages of inhibition, i.e. $\mathrm{EC}_{20}, \mathrm{EC}_{50}$ and $\mathrm{EC}_{80}$. Toxicity measurements are carried out at 15 and 30 minutes contact times.

\section{Analytical procedure}

Apart from COD, all analyses for conventional characterization and tannic acid measurements were performed as defined in Standard Methods (APHA, AWWA and WPCF, 1998). COD measurements were accomplished by ISO 6060 method (ISO, 1986). All experiments were conducted at room temperature. $\mathrm{pH}$ adjustments were made by $\mathrm{NaOH}$ or $\mathrm{H}_{2} \mathrm{SO}_{4}$ solutions. Filtrates of samples subjected to vacuum filtration by means of Millipore membrane filters with a pore size of $0.45 \mu \mathrm{m}$ are 
defined as soluble fractions. Each data point was calculated as the mean of three replicate measurements.

\section{RESULTS AND DISCUSSION Inert COD levels}

According to the outcomes of the inert COD tests outlined in Table 2; $75 \%$ and $77 \%$ tannic acid removals are obtained for Tannin 1 and Tannin 2 respectively.

Table 2. Results of the inert COD experiments for Tannin 1 and Tannin $2\left(\mathrm{mg} \mathrm{l}^{-1}\right)$

\begin{tabular}{|c|c|c|c|c|}
\hline & \multicolumn{2}{|c|}{$\begin{array}{c}\text { Reactor I } \\
\text { fed with wastewater }\end{array}$} & \multicolumn{2}{|c|}{$\begin{array}{c}\text { Reactor II } \\
\text { fed with glucose }\end{array}$} \\
\hline & Soluble COD & Tannic Acid & Soluble COD & Tannic Acid \\
\hline & \multicolumn{4}{|c|}{ TANNIN 1} \\
\hline Start of the experiment & 1050 & 65 & 905 & - \\
\hline End of the experiment & 630 & 16 & 30 & - \\
\hline Duration (days) & \multicolumn{2}{|c|}{100} & \multicolumn{2}{|c|}{100} \\
\hline & \multicolumn{4}{|c|}{ TANNIN 2} \\
\hline Start of the experiment & 1200 & 245 & 860 & - \\
\hline End of the experiment & 515 & 57 & 35 & - \\
\hline Duration (days) & \multicolumn{2}{|c|}{90} & \multicolumn{2}{|c|}{90} \\
\hline
\end{tabular}

The total COD, $\mathrm{C}_{T}$, of wastewaters can be grouped into of two main fractions: The inert COD, and the biodegradable COD. The outlet of a properly designed and well operated biological treatment system does not contain any biodegradable COD fractions due to the fact that all the biodegradable organics will be removed within the treatment plant. Particulate inert COD fractions leave the treatment facility by sludge wastage. The soluble inert COD of the wastewaters, $S_{l}$, gains importance as it by-passes the biological treatment system without being involved in the biochemical reactions. On the other hand soluble residual microbial products, $S_{\mathrm{p}}$, are generated through the course of biochemical reactions during biodegradation. Soluble residual (inert) microbial products, $S_{P}$, and the inert COD of influent origin, $S_{\text {I, }}$ together control the magnitude of effluent soluble COD level obtained at the outlet of a biological treatment plant. In other words, the effluent soluble COD of a properly designed and well operated biological treatment plant is composed of $S_{P}+S_{l}$, which has to be lower than the discharge standards. Total and residual COD contents of segregated textile-bath discharges carrying tannin formulations are outlined in Table 3.

Table 3. Characteristics of segregated dye-bath discharges carrying various textile tannins

\begin{tabular}{lccccl}
\hline Textile Auxiliary & $\begin{array}{c}\text { Total COD } \\
\mathbf{C}_{\mathbf{T}}\left(\mathrm{mg} \mathrm{l}^{-1}\right)\end{array}$ & $\begin{array}{c}\text { Initially Inert } \\
\text { Soluble COD } \\
\mathbf{S}_{\mathbf{I}}\left(\mathrm{mg} \mathrm{l}^{-1}\right)\end{array}$ & $\begin{array}{c}\text { Residual COD* } \\
\mathbf{S}_{\mathbf{+}} \mathbf{S}_{\mathbf{P}} \\
\left(\mathrm{mg} \mathrm{l}^{-1}\right)\end{array}$ & $\begin{array}{c}\mathbf{S}_{\mathbf{I}} / \mathbf{C}_{\mathbf{T}} \\
(\%)\end{array}$ & Reference \\
\hline Natural Tannin & 1100 & 25 & 100 & 2 & Germirli et al., 2007 \\
\hline Synthetic Tannin & 465 & 135 & 190 & 29 & Germirli et al., 2007 \\
\hline Tannin 1 & 1050 & 620 & 630 & 59 & This study \\
\hline Tannin 2 & 1200 & 490 & 515 & 41 & This study \\
\hline
\end{tabular}

* at the outlet of a well operated biological treatment facility

The total COD contents $\left(\mathrm{C}_{\mathrm{T}}\right)$ given in table indicates the application of synthetic tannin as the most favourable outcome since a lower COD is introduced to the segregated textile-bath discharge in this case. Natural Tannin, Tannin 1 and Tannin 2 formulations yield similar total COD values ranging from $1050 \mathrm{mg} \mathrm{l}^{-1}$ to $1200 \mathrm{mg} \mathrm{l}^{-1}$. It must be noted that such an evaluation based on solely total COD levels will not lead a sound result. A correct conclusion can be drawn from the data on initially inert soluble COD and residual COD levels. Although Natural Tannin formulation imparted one of the highest total COD level, i.e. $1100 \mathrm{mg} \mathrm{I}^{-1}$, only $2 \%$ of this organic input yielding $25 \mathrm{mg} \mathrm{I}^{-1} \mathrm{COD}$ can be considered as initially inert (Germirli et al., 2007). Therefore the segregated wastewater stream containing natural tannin did not necessitate any pretreatment to improve its biodegradability (Germirli et al., 2007). Both of Tannin 1 and Tannin 2 formulations on the other hand, are observed 
to contain high levels of initially inert soluble COD, $\mathrm{S}_{\mathrm{l}}$, accounting for 59 and $41 \%$ of the total COD, respectively. The mentioned high $S_{\text {| }}$ values associated with Tannin 1 and Tannin 2 indicate the requirement of a specific pretreatment on segregated effluents containing these formulations. When the textile-bath discharges containing the tannin formulations are comparatively evaluated in terms of the lowest achievable COD levels after biotreatment, again natural tannin, with a residual COD of $100 \mathrm{mg} \mathrm{l}^{-1}$, is monitored to yield the best outcome. The results obtained on Tannin 1 and Tannin 2 show that these formulations have around $630 \mathrm{mg} \mathrm{l}^{-1}$ and $515 \mathrm{mg} \mathrm{l}^{-1}$ of residual COD, respectively.

\section{Toxicity}

The results of toxicity tests performed with marine bacteria Vibrio fischeri are plotted on Figure 2 and Figure 3.
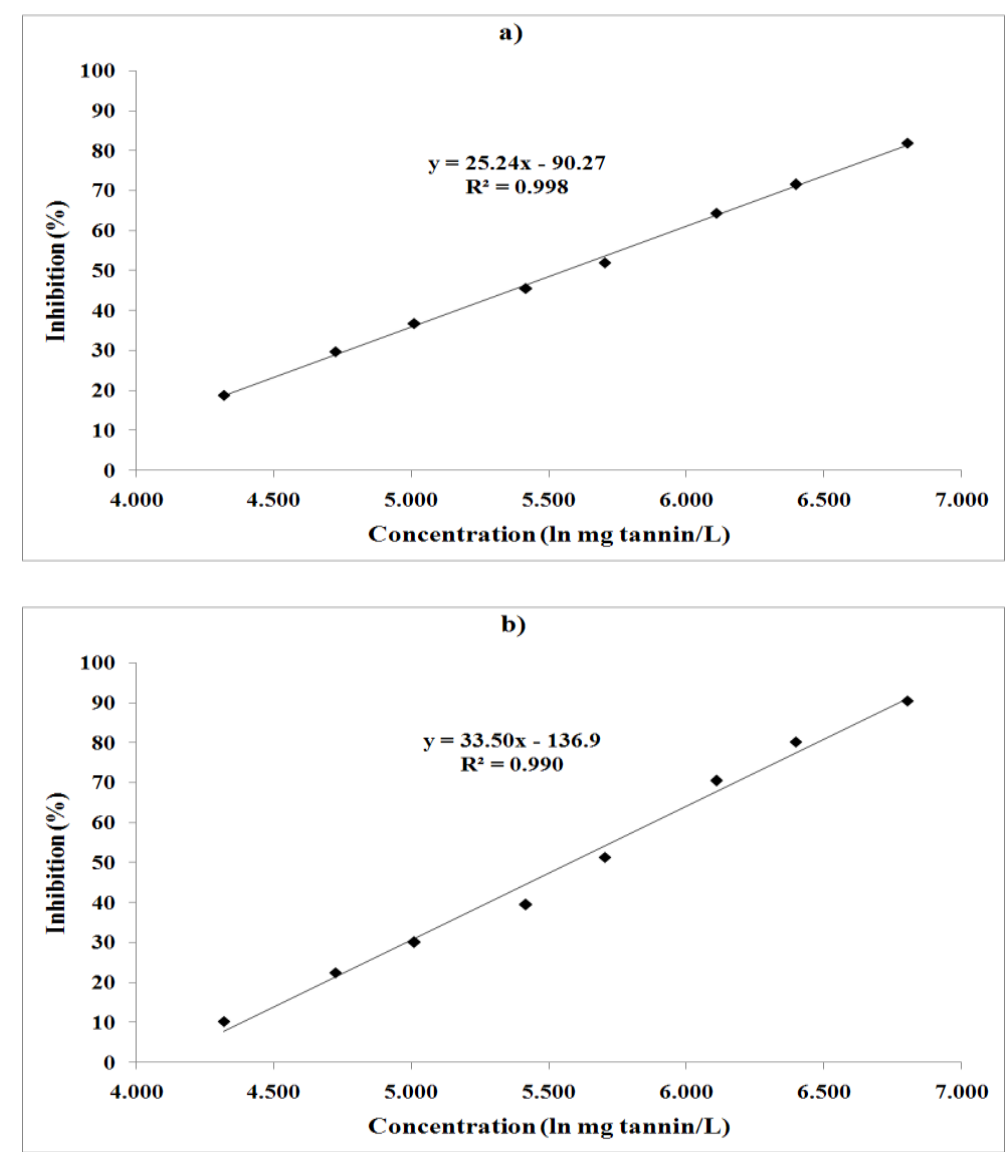

Figure 2. Plots of toxicity tests for Tannin 1 at a) 15 and b) 30 minutes contact time

Effective concentrations causing different percentages of inhibition, i.e. $\mathrm{EC}_{20}, \mathrm{EC}_{50}$ and $\mathrm{EC}_{80}$ for both of the tannin formulations are tabulated in Table 4.

Table 4. Effective concentrations causing different percentages of inhibition (mg tannin ${ }^{-1}$ )

\begin{tabular}{ccccccc}
\hline Contact Time $\rightarrow$ & \multicolumn{3}{c}{ 15 minutes } & \multicolumn{3}{c}{ 30 minutes } \\
\hline Test Substance $\downarrow$ & EC $_{\mathbf{2 0}}$ & EC $_{\mathbf{5 0}}$ & EC $_{\mathbf{8 0}}$ & $\mathbf{E C}_{\mathbf{2 0}}$ & EC $_{\mathbf{5 0}}$ & EC $_{\mathbf{8 0}}$ \\
\hline Tannin1 & 80 & 260 & 850 & 110 & 265 & 650 \\
\hline Tannin 2 & 16 & 50 & 155 & 24 & 63 & 170
\end{tabular}

According to the values presented in the table segregated effluents containing both of the tannin formulation can be considered as highly toxic as both of them contain $1000 \mathrm{mg}$ of tannin formulation per litre. Tannin 2 is observed to exert considerably high toxicity when compared with Tannin 1. 

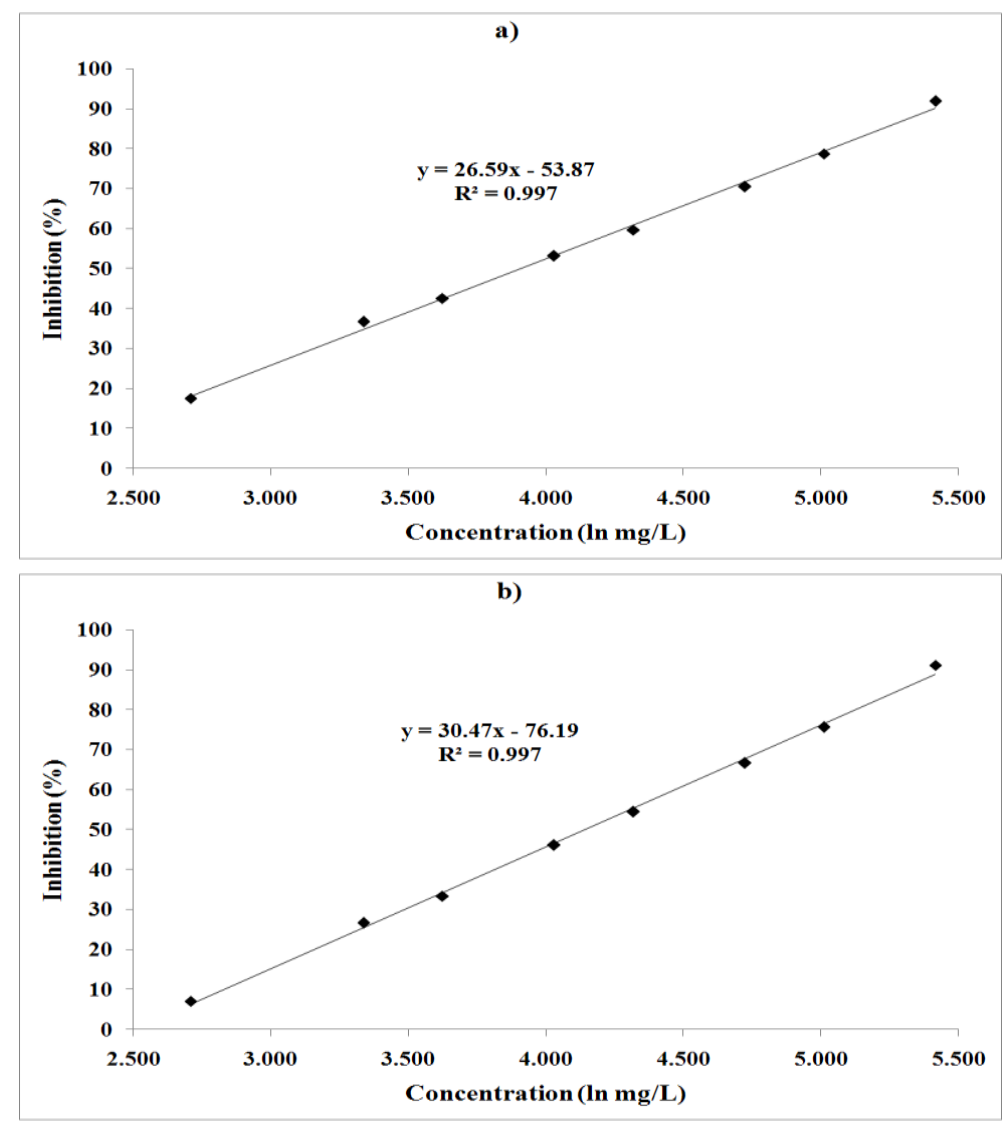

Figure 3. Plots of toxicity tests for Tannin 2 at a) 15 and b) 30 minutes contact time

\section{CONCLUSIONS}

A comparative evaluation covering inert COD contents and toxicities towards marine bacteria Vibrio fischeri, performed on two commonly applied textile tannins is presented in this study.

Textile baths containing both of Tannin 1 and Tannin 2 formulations are monitored to have high levels of initially inert soluble COD, $\mathrm{S}_{\mathrm{l}}$, accounting for 59 and $41 \%$ of the total COD, respectively. These high levels of recalcitrance together with the lowest achievable COD values after biotreatment (accounting $630 \mathrm{mg} \mathrm{I}^{-1}$ and $515 \mathrm{mg} \mathrm{I}^{-1}$ of residual COD for Tannin 1 and Tannin 2, respectively) indicate the requirement of a specific pretreatment on segregated effluents containing these formulations.

Segregated textile baths containing both of the tannin formulations can be considered as toxic towards marine bacteria Vibrio fischeri. Tannin 2 is determined to exert considerably higher toxicity than Tannin 1.

\section{ACKNOWLEDGEMENTS}

This study was supported by The Research and Development Fund of Istanbul Technical University.

\section{REFERENCES}

APHA, AWWA and WPCF, 1998. Standard Methods for the Examination of Water and Wastewater, American Public Health Association, Washington, DC. $20^{\text {th }}$ Edition.

Arslan Alaton I., Iskender G., Ozerkan,B., Germirli Babuna F. and Okay O. (2007), Effect of Chemical Treatment on the Acute Toxicity of Two Commercial Textile Dye Carriers', Water Science and Technology, 55(10), 253-260.

Arslan Alaton I., Okay S.O., Eremektar G. and Germirli Babuna F. (2006a), Toxicity Assessment of Raw and Ozonated Textile Biocides, International Magazine for Textile Design Processing and Testing AATCC Review, 6(5), 43-48. 
Arslan-Alaton I., Insel G., Eremektar G., Germirli Babuna F. and Orhon D. (2006b), Effect of Textile Auxiliaries on the Biodegradation of Dyehouse Effluent in Activated Sludge, Chemosphere, 62(9), 1549-1557.

Burkinshaw S. M. and Bahojb-Allafan B. (2003), The development of a metal-free, tannic acid-based after treatment for nylon 6,6 dyed with acid dyes-part1: Initial studies, Dyes and Pigments, 58, 205-218.

Germirli Babuna F., Yilmaz Z., Okay O., Arslan Alaton I.and Iskender G. (2007), Ozonation of Synthetic versus Natural Textile Tannins: Recalcitrance and Toxicity towards Phaeodactylum tricornutum, Water Science and Technology, 55(10), 45-52.

Germirli F., Orhon D., Artan N., Ubay E. and Görgün E. (1993), Effect of two-stage treatment on the biological treatability of strong industrial wastewaters, Water Science and Technology, 28(2), 145-152.

Heinlaan M., Ivask A., Blinova I., Dubourguier H.C. and Kahru A. (2008), Toxicity of nanosized and bulk $\mathrm{ZnO}, \mathrm{CuO}$ and $\mathrm{TiO} 2$ to bactreria Vibrio fischeri and crustaceans Daphnia magna and Thamnocephalus platyurus, Chemosphere, 71(7), 1308-1316.

ISO (1986). Water Quality - Determination of the Chemical Oxygen Demand, Ref. No. ISO 6060-1986. 